\title{
UNCOVERING THE GERMAN ABORIGINE
}

\section{Oliver Haag}

Jeannie Gunn, Die kleine schwarze Prinzessin aus dem Never-Never, trans. Leni Tschudi-Rüegg. Leipzig: Araki, 2010, 125pp, ISBN: 9783936149395. € 12.90.

Anne Saunders, Reisen in die Traumzeit. Eine Aboriginaleinweihung, trans. Jan Leichsenring. Leipzig: Araki, 2009, 200pp, ISBN: 9783936149371. € 14.50

William Peasley, Die letzten Nomaden, trans. Johanna Ellsworth. Leipzig: Araki, 2007, 173pp, ISBN: 978-3222125379. € 16.90

T he translation of literature is not only of literary concern, but also one of politics and history, particularly so if translations involve racial representation (King). The matter of racial representation has become apparent in three recent translations of Australian books, all issued by Araki, a small Leipzig-based publisher. Araki's publishing programme includes Aboriginal-related books, one of them with an esoteric twist, German literature, and general esoteric literature. Part of Aboriginal-related translations in the programme are the Australian children's classic Die kleine schwarze Prinzessin aus dem Never-Never (original: The Little Black Princess, 1905); an esoteric book on interracial reconciliation entitled Reisen in die Traumzeit (original: $A$ Geomythical Journey, 2001); and Die letzten Nomaden (original: The Last of the Nomads, 1982), a widely-sold book in Australia about the isolated life of two members of the Mandildjara people in the Gibson Desert. 
The most challenging of the translations is Jeannie Gunn's Die kleine schwarze Prinzessin aus dem Never-Never (2010). Written more than a century ago, the first-person story is set in the Katherine district and revolves around the friendship between Jeannie Gunn, a white farmer's wife, and an Aboriginal girl named Bett-Bett. The story includes accounts of Aboriginal customs, social life and material culture, all of which is described in a jargon that can be considered racist, at least how we understand the term today. This includes derogatory terms, such as "nigger", "Piccaninny" and "lubra", some of them amended in the subsequent re-editions. Yet not only particular terms, but also the entire character of the story render the original text prejudiced. Gunn's book is sympathetic to the Aboriginal protagonists, to be sure, but describes Aboriginal people as awkward, childish and intellectually inferior to white people. Bett-Bett's uncle, for example, is depicted as too retarded to know how to put on the trousers that Gunn gives him to cover his modesty (Gunn 1906:1314). Such racial references to imbecility, nudity and civilisation permeate the whole of the original text. Scholarship concludes that, although Gunn's text may have espoused a well-intentioned view of Aboriginal people at the time of its production, today it indubitably comes across as racist (Ellinghaus 1997; Larbalestier 1990).

Any translation of Gunn's text thus inevitably replicates early twentieth century racist discourse. But in the German version the translator has not even tried to replace the most obnoxious racist terminology-only the word "nigger" is given as "Eingeborene" (Gunn 1906:xiv; Gunn 2010:10). Although less extreme than "nigger", the word "Eingeborene" still carries a racist connotation. Moreover, such humiliating words as "lubra" and "Piccaninny"-referring to Black women and children, respectively-have simply been kept on in the German translation. Another form of racist replication is the quite direct translation of Gunn's version of Aboriginal English. For instance, the sentence, "Spose me shut him eye quickfellow, that all right" (Gunn 1906: 17) has been rendered into German thus: "Wenn mich schließt ihm Auge ganz geschwind, macht nichts" (Gunn 2010:23). Literally translated into English this sentence reads, "If I close my eyes very quickly then it does not matter". This unidiomatic language 
represents the Aboriginal protagonists as incapable of producing proper language, and also misrepresents Aboriginal English as a faulty version of Standard English. In German, the representation of racial minorities through faulty German is one of the most vulgar elements of racist discourse.

All of this, however, does not mean that such a text should not in principle be translated. The book is certainly of interest to academics and specialist readers interested in the history of racism in Australian literature. But any serious translation of Gunn's book requires proper contextualisation according to the text's historicity, ideally provided in a substantial introductory chapter. Alas, this is nowhere the case in the present German translation. Far from employing a critical approach to racial discourse past and present, the book is simply conceived of as suitable for children, with children being directly addressed on the blurb by the personal pronoun $d u$. Clearly, a young, non-academic readership is the wrong addressee for such a book. But it gets even worse when the translator stresses in the epilogue the truthfulness of Gunn's accounts:

Das vorliegende Buch ist der erste authentische Bericht, der über das Leben und die seltsamen Sitten und Gebräuche der Ureinwohner Australiens veröffentlicht worden ist. Er wurde vor mehr als hundert Jahren geschrieben und in der Zwischenzeit sind unzählige Publikationen über die Ureinwohner erschienen. Aber das Buch hat nichts von seinem ursprünglichen Wert und seiner Frische verloren. (Gunn 2010:120)

In English this passage reads,

The present book is the first authentic account that was published on the odd mores and customs of the Natives of Australia. It was written more than a hundred years ago and, meanwhile, countless publications have appeared about the Aborigines. But this book has lost nothing of its original value and freshness (...)

The naïveté and obvious lack of any knowledge of Australian Aboriginal history and culture evinced in the translation of the text give the impression that the blatant racism in the book was not merely the product of the historic author, but also one of the modern translator and publisher. 
Racial representation is also evident in Reisen in die Traumzeit (2007), which is strikingly reminiscent of Marlo Morgan's best-seller Mutant Message Down Under (1991), a literary hoax passed off as a true account by a white American woman seeking spiritual enlightenment among Aboriginal people. Written by Anne Saunders, a Scottish émigré to Australia, and self-published in 2001, Reisen in die Traumzeit (2007) tells of the author's epiphany to reconcile the Celtic race with the Aboriginal and Māori peoples. This epiphany, the author says, was instigated by her eagle totem, along with a couple of orders sent from the Pleiades. Having received the spiritual order, Saunders chronicles her experiences of healing the different pasts and of penetrating the boundaries between the Aboriginal, Māori and Celtic races. The reconciliation with the past-massacres and genocide are casually referenced-is played out on a spiritual level through engaging with ancient spirits and, little wonder, the healing is not resolved at the end of the book.

The book is far too removed from reality to be worthy of serious review. But there are remarkable forms of racial representation in this book. First, it testifies to esoteric discourse having embarked on the political process of reconciliation. The reconciliation thereby turns out to be a form of self-sufficient healing, that is, a healing of the author's own ancestral past and, potentially, her readership's ancestral pasts, leaving out the healing for Aboriginal and Māori peoples. Second, the author establishes a common nexus between Celtic (i.e., Scottish and Irish), Aboriginal and Māori peoples, since all three cultures, the argument runs, would have been characterised by a non-materialistic and highly spiritual lifestyle, with the Scots and Irish sharing the same historical suffering at the hands of the English as Indigenous New Zealanders and Australians $(9,10,43)$. The reconciliation is thus achieved by the creation of a common racial bond between Nordic and Indigenous peoples, hence the adoption of a European Indigenous identity. This adoption also works for a German-speaking readership that can harken back to an idea of a close-to-Celtic, that is, Germanic Indigeneity. 
The third form of racial representation in this book is through conceiving Aboriginal Australians as pure and endowed with spirituality. Reconciliation, the author argues, needs to be achieved through a direct relation with Aboriginal people, which in turn, she claims, could not be established on a rational level, but only by transgressing the boundaries of human intellect (13). Significantly, the author states that "the desert dwellers in all their simplicity, humanity and purity are still something special" (30; translation mine). Aboriginal people here are presented through the prism of traditionalism and racial purity, the latter bearing inevitable references to skin colour. It is difficult not to discern the racist content of the representation of Aboriginal people evinced in this piece.

Racial representation is less prejudiced in Die letzten Nomaden (2007), the German edition of The Last of the Nomads (1982), authored by William Peasley, a physician and anthropologist. The book rests on Peasley's true account of the married couple Warri and Yatungka Kyangu, who, having disobeyed Mandildjara marriage rules, escaped to the Gibson Desert. Until their death in the 1970s, the couple led an isolated and traditional life and became what is said to be the last of the desert nomads, long after the Mandildjara people had given up their nomadic customs. The book tells of Peasley"s efforts to find the elderly couple and document their traditional lifestyle.

In the German translation of The Last of the Nomads (1982) no racist terminology has been employed. As with the other two books discussed in this essay, the translation itself reads fluently. There are only a few awkward renditions, such as the word for "initiation", which is given as Einweihungsprozess, which carries the meaning of an induction to a potential secret. The correct word would have been Initiation. But such examples of misleading translation are rare.

The difficulty with this book thus lies less in the process of translation than in the conception of Aboriginality that it evokes in a Germanspeaking readership. The emphasis on the last of the nomads represents Aboriginal people as being part of the past and caters to an interest in the original and pure. Significantly, the book closes with the 
words, "Ein Kapitel der australischen Geschichte war abgeschlossen, eine Ära war zu Ende gegangen" (167), meaning that with the end of the last nomads an era of Australian history also came to an end. Whereas this may have been the case with the two protagonists, the trope of the "last people" nonetheless implicates the notions of a vanishing race, running the risk of conceiving culture as a calcified and essentialist category (Birch; Lattas). No text is free of its sociohistorical contexts. In the case of The Last Nomads, paradigms of assimilation, the dying race dogma and ideas of Aboriginal traditionalism would have needed to be critically analysed, at best in a substantial introduction. As it stands, the text can easily invoke the idea of the last Nomad as the true Aborigine.

For all their thematic differences, the three books published by Araki share one similarity-all of them portray Aboriginal culture exclusively as traditional and completely opposed to Western culture. Aboriginal Australians are thereby represented as part of the past and those of them who do not fit this stereotype are not represented as Aboriginal. Quite obviously, this obsession with traditionalist otherness panders to romantic ideas of a pristine and unadulterated people. It is the idea of the German Aborigine, the Aborigine that fulfils these romantic perceptions, that is fostered by the translation of such books, especially so if they are not critically annotated. With its restrictive focus on traditionalist stories, Araki has helped create the German Aborigine. Translation indeed is a highly political endeavour.

\section{References}

Birch, Tony, 1993. "'Real Aborigines" - Colonial Attempts to Re-

Imagine and Re-Create the Identities of Aboriginal People", Ulitarra 4, 13-21.

Ellinghaus, Katherine 1997. "Racism in the Never-Never:

Disparate Readings of Jeannie Gunn", Hecate 23:2, 76-94.

Gunn, Aeneas Mrs., 1906. The Little Black Princess. A True

Tale of Life in the Never-Never Land. London: Melville \& Mullin.

King, Homay, 2010. Lost in Translation. Orientalism, Cinema,

and the Enigmatic Signifier. Durham, North Carolina: Duke University Press. 
Larbalestier, Jan, 1990. "Amity and Kindness in the Never-

Never: Ideology and Aboriginal-European Relations in the Northern Territory", Social Analysis 27, 70-82, 119-129.

Lattas, Andrew, 1993. "Essentialism, Memory and Resistance:

Aboriginality and the Politics of Authenticity', Oceania 63:3, 240-267.

Morgan, Marlo, 1994. Mutant Message Down Under. New York:

HarperCollins.

Peasley, William, 1982. Last of the Nomads. Fremantle:

Fremantle Arts Centre Press.

Saunders, Anne, 2001. My Geomythical Journey. Alice Springs:

Oracle Press. 